\title{
PERAN ISLAM DALAM PENYELAMATAN LINGKUNGAN
}

Oleb : Ari Handriatni

Abstract

Islam is a religion which concerns greatly towards the environment. Allab Says in many verses in Alquran that man must preseve the nature and prevent to distruct on earth. Our Prophet Muhammad has instructed to buman kind to love animals, keep clean, and not to cut trees cruelly. The fact presently shows that environment is sufferring from an enormous damage. Islam should stand in the lead to prevent such destruction and show great effort to save. The effective means to persue this objective is by Dakwab. Therefore dakwah which has been done needs to be involved by the issue of environment. Enviromental Dakwah should be passed vigorously through the dakwab channels and medias. The effectiveness of dakwah will motivate the people to care for the nature.

نحال)

يمنح الإسلام اهتماماً كبيراً للبيئة، فالقرآن الكريم يهفل بالعديل من الآيات الداعية إلى اللحفاظ على الطبيعة واللجيلولة دون الفساد في الأرض. كما يوجه النبي محمد الإنسان إلى حب اللميوانات، اللحفاظ على النظافة، وعلم الملور على الأشجار. إلا إن الواقع اليوم يظهر أن البيئة تعاني من كثير من الفساد للدرجة توجبب أن يقف الإسالام، .ما يمويه من تقلدير تحو البيئة، موقف القائد لمنع إفساد البيئة وإظهار بحهود كبير في الحفاظ عليها. ومن أجل تحقيق هذا تبدو اللدعوة وسيلة فعالة عبر إضافة قضية البيئة إلى أجندما. إن "اللدعوة البيئية" يجب أن تمرر بقوة من خلال القنوات والوسائط اللعوية الأخرى، على أمل أن تؤدي فعاليتها إلى تحفيز النابس على اللحفاظ على بيئهـم. Keywords : Dakwah, life enviroment, damage, facility and dakwab media.

* Penulis adalah Dosen Tetap Universitas Pekalongan dan alumni Program Pasca Sarjana Universitas Gadjah Mada Yogyakartaarif_tahman_07@yahoo.com.sg 


\section{A. Pendabuluan}

Sebagai agama yang mempunyai predikat rabmatan lil 'alamin, Islam mengajarkan kepada pemeluknya untuk selalu berinteraksi dengan lingkungan secara baik. Sebab, Allah telah menciptakan alam semesta untuk manusia agat dipergunakan sebaikbaiknya demi perbaikan kualitas dan kesejahteraan kehidupan.

Dalam penciptaan alam, Allah juga menurunkan hukum-hukum yang berkaitan dengannya. Hukum yang berkaitan dengan alam merupakan hukum sebab akibat yang sering disebut sebagai "Hukum Alam" yang biasa disebut dengan Sunatullah. Hukum-hukum tersebut diperlukan untuk kebetlangsungan pelestarian alam dan manusia sekaligus menjadi peringatan bagi manusia yang melanggarnya. Manusia, terutama umat Islam, yang menjadi khalifab di muka bumi diharuskan mengetahui hukum-hukum tersebut agar alam semesta yang diciptakan untuk mereka dapat dimanfaatkan secara terus menerus. Tentang penciptaan alam semesta beserta hukum-hukumnya ini Allah berfirman di dalam $\mathrm{Al}$ Quran yang artinya:

Sesunggubnya Tuban kamu ialah Allah yang telab menciptakan langit dan bumi dalam enam masa, lalu Dia bersemayam di atas 'Arsy. Dia menutupkean malam kepada siang yang mengikutinya dengan cepat dan matabari, bulan dan bintang-bintang tunduk kepada perintab-Nya. Ingatlah, menciptakan dan memerintab banyalab bak Allab. Maha Suci Allah, Tuhan semesta alam.'

Kerusakan yang demikian parah saat ini membutuhkan suatu langkah konkrit penyelamatan. Sebagai manusia yang beragama, dengan memperhatikan tuntunan Ilahi, akan mengetahui bahwa apabila Hukum Alam (Sunatullah) dilanggar, maka manusia akan merasakan akibatnya. Ayat yang terkenal dan sering dikutip mengenai kerusakan lingkungan adalah

Al Quran yang artinya :

Telah nampak kerusakan di darat dan di laut disebabkan perbuatan tangan manusi, supaya Allah merasakan kepada mereka sebahagian dari perbuatan mereka, agar mereka kembali. ${ }^{2}$

Kerusakan alam, sebagai akibat dilanggarnya Sunatullah diharapkan akan menyadarkan dan mengembalikan manusia pada fitrahnya, yaitu memelihara alam semesta yang menjadi tempat tinggalnya.

${ }^{1}$ QS al-A'raf (7): 54

${ }^{2} \mathrm{QS}$ ar-Rum (30) : 41 


\section{B. Fakta Kerusakan Alam}

Fakta terjadinya kerusakan alam saat ini tidak dapat dipungkiri, terutama dibumi Indonesia, kerusakan alam yang terjadi akhir-akhir ini akibat dari kerusakan alam sangat berdampak terhadap kehidupan manusia. Wahana Lingkungan Hidup (WALHI), lembaga swadaya masyarakat yang aktif menyerukan pencegahan kerusakan dan pemeliharaan lingkungan dalam laporan tahunan pada ulang tahun yang ke-25 tahun 2005 lalu membeberkan kerusakan alam yang terjadi, khususnya di daerah Indonesia.

Setiap tahun kita menghasilkan jutaan ton sampah yang tak terkelola dengan baik, belum banjir sampah impor yang mengandung bahan berbahaya beracun. Udara di kota-kota besar tercemar logam berat karena kontrol yang lemah atas aktivitas industri serta buruknya sistem transportasi yang memaksa kita untuk menggunakan berbagai jenis kendaraan bermotor yang justru penyumbang bagi menyebarnya logam berat ke udara. ${ }^{3}$

Para ilmuwan telah menunjukkan dengan penelitian intensif bahwa planet bumi telah terancam. Selain itu akibat perubahan iklim dan kehilangan habitat dan ekspansi yang dilakukan oleh manusia, kepunahan spesies semakin bertambah tinggi. Sedikitnya ada 15 spesies telah punah dalam 20 tahun terakhir, 12 spesies dapat bertahan hidup karena dipelihara dan ditangkarkan oleh manusia. Namun, diyakini bahwa sebenarnya spesies yang mengalami kepunahan jumlahnya jauh lebih besar. Lebih dari itu menurut penelitian Global Species Assessment (GSA) dalam Siaran Pers bulan November 2004, sekitar 15.589 spesies yang terdiri dari 7.266 spesies satwa dan 8.323 spesies tumbuhan dan lumut kerak, diperkirakan berada dalam resiko kepunahan. ${ }^{4}$

Millennium Ecosystems Assessment Report (2005) memberitahukan kepada kita, bahwa manusia sekatang ini sedang membinasakan sistem yang menyokong kehidupan mereka sendiri dalam taraf yang mengkhawatirkan. Data-data menunjukkan bahwa manusia yang menjadi penyebab perubahan iklim, meracuni udara, air, dan tanah; sehingga kesehatan manusia - termasuk semua spesies - yang ada ikut terancam keberadaannya. Selain itu, ledakan populasi dalam abad 20 dari 2 menjadi 6 milyar penduduk akan menyebabkan kendala yang akan berbenturan dengan masalah sumber daya alam. Para ilmuwan telah mendokumentasikan bahwa kita hidup di tengah ancaman kepunahan periode keenam, yang diindikasikan oleh banyaknya spesies yang punah pertahun. Sekarang ini dinyatakan, lebih dari 10.000 spesies setiap tahun yang bermakna, bahwa periode seperti ini adalah sama dengan lajunya kepunahan spesies dalam 65 juta tahun, di mana saat itu dinosaurus turut musnah.

\footnotetext{
${ }^{3}$ Pernyataan 25 tahun Wahana Lingkungan Hidup Indonesia: Saatnya Kita Berubah, Siaran Pers, 15
} Oktober 2005, wwwwwalhi.org

' Fachruddin Mangunjaya (2005), Agama Mengatasi Krisis Lingkungan, www.tropika.ot.id 
Dengan kata lain, kita sedang mematikan sistem kehidupan kita sendiri di planet bumi dan mendahului era geologis yang sedang berjalan. ${ }^{5}$

Apa yang kemudian terjadi dengan sumber daya alamnya yang terbatas ini? Menurut seorang ahli bidang kependudukan, Colin Clark, sumber-sumber alam di bumi hanya dapat menampung maksimal 12 sampai 15 miliat manusia. ${ }^{6}$

Lary Gonick dan Alice Outwater dalam pembukaan bukunya mengetengahkan contoh konkrit kerusakan lingkungan yang menyebabkan hampir punahnya kehidupan yang diderita oleh penduduk Pulau Paskah. Pulau yang paling terpencil di dunia tersebut hanya berukuran $165 \mathrm{~km}$ persegi dan terletak di Samudra Pasifik. Pulau tersebut jauhnya $3.700 \mathrm{~km}$ dari segala penjuru. Ketika Roggerveen, Laksamana dari Belanda yang datang ke pulau itu pada tahun 1722, tercatat sekitar 3.000 penghuni pulau itu bertahan hidup dalam kondisi yang sangat mengenaskan. Mereka hanya menanam pisang, tebu dan ubi jalar di tanah yang gersang dan berbatu. Satusatunya sumber air tawar adalah danau-danau tohor di kawah. Jarang ada pohon di pulau itu dan penduduknya "kecil, kerempeng dan melarat".

Kegiatan luang masyarakat Polinesia pada waktu itu adalah memahat patung dan kemudian betkembang patung yang dihasilkan besar-besar (ciri khas Pulau Paskah adalah patung berukuran besat yang bertebaran di seantero pulau, berjajar rapat memunggungi laut). Patung-patung tersebut dibuat di pedalaman, diangkut dan dipindahkan ke pantai dengan bantuan kayu gelondongan dan tali. Seorang geolog Amerika Charles Love melakukan percobaan dengan merekonstruksi ulang bagaimana dahulu penduduk pulau memindahkan patung dengan menggunakan kayu gelondongan. $^{8}$

Penggunaan batang pohon untuk memindahkan patung telah membuat penduduk menebangi hutan. Menjelang tahun 1400, pohon sudah jarang tumbuh di Pulau Paskah. Dengan ditebangnya pohon-pohon dan akarnya mati, humus kehilangan penahan. Lapisan tanah setebal 1-1,5 meter akhirnya terkikis dan tidak ada jalan pintas untuk memulihkannya. Tanpa hutan yang menyerap hujan dan mengisi kembali air tanah, sungai dan mata air, pulau menjadi kering. Udara kurang lembab dan curah hujan menyusut. Humus yang subur tergerus membuat hasil panen merosot. Tidak ada lagi kayu untuk membuat rumah dan tidak ada lagi serat untuk jala atau layar. Tidak ada kayu gelondongan untuk membuat sampan.

Berkurangnya sumber daya alam secara drastis akhirnya membuat perang saudara di pulau tersebut untuk memperebutkan sumber daya yang sangat sedikit

\footnotetext{
${ }^{5}$ Mary Evelyn Tucker dan John Grim, Kebangkitan Aliansi Agama dan Ekologi, www.tropika.or.id

${ }^{6}$ Harian Pikiran Rakyat edisi 7 Juni 2004

${ }^{7}$ Larry Gonick dan Alice Outwater, "The Cartoon Guide to The Environment" terjemahan Ismunandat dan Tim KPG (2004), Kartun Lingkungan, Jakarta : Kepustakaan Populer Gramedia, p. 2

${ }^{8}$ Ibid. p. 6
} 
itu. Jumlah penduduk pulau akhirnya merosot tajam. Tahun 1550 masih berjumlah sekitar 7.000 jiwa dan ketika Barat menemukan pulau tersebut pada tahun 1722 penduduknya tinggal sekitar 3.000 jiwa.9

Pulau Paskah adalah contoh nyata sebuah dunia yang bisa jadi akan bernasib sama. Planet bumi ini walaupun jauh lebih besar dari Pulau Paskah, tetaplah tetbatas. Seperti halnya penduduk Pulau Paskah, kita juga dapat melihat seluruhnya dan seperti mereka juga, kita tidak punya sarana untuk selamat. ${ }^{10}$

Akankah kita menunggu nasib planet bumi seperti Pulau Paskah ? Sudah saatnya, umat Islam sebagai umat yang dinyatakan terbaik (khairu ummah) di antara umat-umat lain memberikan contoh bagaimana menahan dan menangani kerusakan alam. Sebagai umat pengemban misi rabmatan lil 'alamin, ajaran Islam tentang lingkungan hidup harus diterapkan dalam kehidupan sehari-hari. Bagaimana Islam mengatur hubungan antara manusia dan lingkungan hidupnya?

\section{Pandangan Islam Terbadap Lingkungan Hidup}

Islam adalah diin yang syaamil (integral), kaamil (sempurna) dan mutakaamil (menyempurnakan semua sistem yang lain), karena ia adalah sistem hidup yang diturunkan oleh Yang Maha Mengetahui dan Maha Bijaksana. Hal ini didasarkan pada firman Allah di dalam Al Quran yang artinya :

Pada hari ini Aku sempurnakan bagimu agamamu dan Aku cukupkan atasmu nikmatku, dan Aku ridhai Islam sebagai aturan hidupmu. ${ }^{11}$

Tanggung jawab yang diemban manusia merupakan konsekwensi atas manfaat yang telah diterima dari alam yang khusus diciptakan Allah untuk manusia. Firman Allah dalam AI Quran berbunyi :

Dia-lah Allah, yang menjadikan segala yang ada di bumi untuk kamu dan Dia berkehendak langit, lalu dijadikan-Nya tujuh langit. Dan Dia Maha Mengetahui segala sesuatu. ${ }^{12}$

Ajaran Islam menawarkan kesempatan untuk memahami sunatullab serta menegaskan tanggung jawab manusia. Ajaran Islam tidak hanya mengajarkan untuk mengambil manfaat dari sumber daya alam, tetapi juga mengajarkan aturan main dalam pemanfaatannya dimana kesejahteraan bersama yang berkelanjutan sebagai hasil keseluruhan yang diinginkan. Fazlun Khalid, Pimpinan dan Pendiri Lembaga Ilmu Ekologi dan Lingkungan Hidup Islami (Islamic Foundation for Ecology and Envi-

${ }^{9}$ Ibid. p. 11

${ }^{10}$ Ibid. p. 12

${ }^{11}$ QS al-Maidah (5) : 3

${ }^{12} \mathrm{QS}$ al-Baqarah (2) : 29 
ronmental Sciences (IFEES)) mengatakan :

Salah satu Sunnah Rasulullah saw menjelaskan bahwa setiap warga masyarakat bethak untuk mendapatkan manfaat dari suatu sumberdaya alam milik bersama untuk memenuhi kebutuhan-kebutuhan hidupnya sepanjang dia tidak melanggar, menyalahi atau menghalangi hak-hak yang sama yang juga dimiliki oleh orang lain sebagai warga masyarakat. Penggunaan sumberdaya yang langka atau terbatas harus diawasi dan dilindungi. ${ }^{13}$

Apa yang disebut lingkungan menurut Islam mencakup semua usaha kegiatan manusia. Karena itu, Islam memandang lingkungan alami dari dua sudut, yaitu sudut ruang (spasial) dan sudut waktu (temporal).. ${ }^{14}$

Islam menyuruh manusia untuk belajar dari sejarah. Oleh karena itu dapat diperoleh gambaran bagaimana umat terdahulu berinteraksi dengan alam dan bagaimana ganjatan Allah terhadap orang yang taat dan patuh kepada-Nya serta bagaimana pula akibat terhadap orang yang dzalim dan membangkang kepada-Nya. Disebut Allah di dalam Al Quran yang artinya :

Katakanlah ! Berjalanlah di permukaan bumi, kemudian perhatikan akibat orang-orang yang berdusta. ${ }^{15}$

Pada ayat lain Allah menceritakan kehidupan suatu bangsa yang berhasil dan sukses kemudian mengalami kehancuran disebabkan sikap dan perilakun mereka yang melawan aturan-Nya. Firman Allah dalam al-Quran yang artinya :

Dan apakah mereka tidak mengadakan petjalanan di muka bumi dan memperhatikan bagaimana akibat (yang diderita) oleh orang-orang sebelum mereka? Orang-orang itu adalah lebih kuat dari mereka (sendiri) dan Telah mengolah bumi (tanah) serta memakmurkannya lebih banyak dari apa yang Telah meteka makmurkan. dan Telah datang kepada mereka rasul-rasul mereka dengan membawa bukti-bukti yang nyata. Maka Allah sekali-kali tidak berlaku zalim kepada mereka, akan tetapi merekalah yang berlaku zalim kepada diri sendiri. Kemudian, akibat orang-orang yang mengerjakan kejahạtan adalah

${ }^{13}$ WWF-Indonesia (2006), Perlindungan Lingkungan Hidup Bagian Penting dari Ajaran Islam, Press Release WWF-Indonesia tanggal 8 Februari 2006 dalam website www.wwf. or.id

if Djajadiningkrat, Suma T. Dan Budhisantoso S. (penyunting) (1997), Islam dam Lingkungan Hidup, Jakarta :Yayasan Swarna Bhumy

${ }^{15} \mathrm{QS}$ al-An'am (6) : 11

${ }^{16}$ QS Al Quran (30) : 9-10 
(azab) yang lebih buruk, Karena mereka mendustakan ayat-ayat Allah dan mereka selalu memperolok-oloknya. ${ }^{16}$

Perkembangan manusia dan interaksinya dengan komponen lain dalam lingkungan hidup yang dikodratkan sebagai khalifah di muka bumi. Dengan demikian manusia bertanggung jawab terhadap keberadaan dan kesejahteraan manusia dan mahluk hidup lainnya. ${ }^{17}$

Lingkungan hidup manusia dapat berubah, bergantung pada sifat dan niat pengelolaannya. Kehidupan rohaniah di dalam Islam hatus berlangsung atas dasar tujuan yang baik dan berguna bagi kehidupan manusia. Kebersihan batiniah seseorang mengambil peran menentukan atas kebersihan lingkungan hidup. Apabila manusia ingin hidup bersih maka tidak cukup baginya hanya membersihkan diri dan keluarganya, lebih dari itu dia juga diharuskan membersihkan lingkungan tempat tinggalnya. ${ }^{18}$

Islam mengajarkan untuk menjaga kelestarian lingkungan. Selain ayat-ayat alQuran yang telah dikemukakan, hadits Nabi Muhammad Saw tentang bagaimana menjaga lingkungan juga akan banyak kita dapati. Demikian pula pendapat para fukaha yang senantiasa menyelipkan masalah-masalah lingkungan dalam pembahasan kitab fiqhnya. Tentang kebersihan, misalnya, Nabi Muhammad menyatakan :

Sesungguhnya Allah itu baik dan mencintai kebaikan. Dia itu suci dan mencintai kesucian. Dia itu mulia dan mencintai kemuliaan. Dia itu bagus dan mencintai kebagusan. Oleh karena itu, bersihkanlah rumahmu. ${ }^{19}$

Masih soal kebersihan lingkungan, dalam hadits yang lain beliau Saw bersabda:

Jagalah kebersihan dengan segala usaha yang mampu kamu lakukan. Sesungguhnya Allah menegakkan Islam di atas prinsip kebersihan. Dan tak akan masuk surga kecuali orang-orang yang bersih. ${ }^{20}$

Beberapa larangan lain yang disampaikan Nabi Saw berkenaan dengan kebersihan dan keindahan lingkungan, di antaranya :

Rasulullah Saw melarang membuang hajad di bawah pohon yang sedang

\section{${ }^{17}$ Ibid. p.78}

${ }^{18}$ Ibid. $p .84$

${ }^{19}$ Jalaluddin As Suyuthi, al-jami'us Shagir, Maktabah Darul Ihya'ilkutubil Aarabiyyah, Indonesia

${ }^{20}$ Hadits Riwayat at-Thabrani -

${ }^{21}$ Hadits Riwayat Ibnu Adi 
berbuah dan melarang pula membuang hajad di aliran sungai. ${ }^{21}$

Tiga hal yang menjemihkan pandangan, yaitu menyaksikan pandangan yang hijau lagi asti dan pada air yang mengalir dan pada wajah yang tupawan. ${ }^{22}$

Barang siapa menyingkirkan suatu benda yang mengganggu di jalanan yang biasa dilewati kaum muslimin maka ia telah menyimpan satu kebaikan dan apabila kebaikan itu diterima maka ia akan masuk ke dalam surga. ${ }^{23}$

Jika seseorang sedang berjalan di sebuah jalan menemukan sebuah batang berduri dan menyingkirkannya maka Allah akan memuji dan mengampuni segala dosanya. ${ }^{24}$

Tentu saja masih banyak hal-hal lain mengenai perilaku manusia terhadap lingkungan dan efeknya yang disampaikan oleh Rasulullah saw. Belum lagi yang berkaitan dengan mahluk hidup lain yaitu hewan. Tidak sedikit nasihat dan petunjuk Rasulullah saw untuk menyayangi dan melindungi hewan dimulai dari hal-hal yang kecil. Misalnya hadits yang beliau sampaikan berkenaan dengan menolong bintang, seperti yang diriwayatkan oleh Imam Bukhari :

Suatu ketika ada seorang yang banyak dosa yang sedang melakukan perjalanannya dalam keadaan sangat haus, lalu menemukan sumur dan turun ke dalamnya, lalu ia minum dan terus keluar. Tiba-tiba ia melihat seekor anjing yang menjulurkan lidahnya karena kehausan sambil menjilat-jilat di tanah. Maka orang itu turun kembali dan membuka sepatunya lalu mengisinya dengan air lalu ia memanjat kembali dengan menggigit sepatunya agar air tidak jatub untuk memberi minum anjing itu, maka Allah meridhoi orang tersebut dan mengampuni semua dosanya. Maka pata sahabat bertanya : "Ya Rasulullah, apakah pada binatang kita bisa mendapat pahala ?" Maka jawab al-Musthafa Muhammad saw, "Pada setiap jantung yang berdenyut ada pahala."25

Sementara itu berbuat jahat terhadap binatang juga mendapatkan kecaman yang sangat keras kepada pelakunya. Kalau Allah mengganjar surga bagi mereka yang berbuat baik kepada binatang, Allah juga membalas mereka yang jahat kepada binatang dengan neraka. Nabi Muhammad saw menyatakan :

Seorang wanita ahli ibadah disiksa akibat seekor kucing yang dikurungnya

2 Hadits Riwayat Ahmad

${ }^{23}$ Hadits Riwayat Abu Darda'

${ }^{24}$ Hadits Riwayat Ahmad

${ }^{25}$ Hadits Riwayat Bukhari 
sehingga mati kelaparan, maka akibat perbuatannya pada kucing itu wanita itu masuk neraka. Dikatakan kepadanya, "Engkau tidak memberikan makanan atau minuman kepadanya waktu engkau mengikatnya dan engkaupun tidak melepaskannya sehingga ia bisa memakan kutu-kutu yang merayap di tanah sehingga ia mati." ${ }^{26}$

Secara umum Nabi Muhammad saw menyuruh umatnya untuk menyayangi apa-apa yang ada di bumi, yaitu menyayangi sesama manusia, hewan, tumbuhtumbuhan dan alam semesta. Tujuannya agar kecintaan itu menumbuhkan kecintaan balik dari penghuni langit, yaitu Allah dan para malaikat kepadanya. Dalam hadits yang disampaikan oleh Ibn Amr, Rasulullah saw bersabda :

Orang-orang yang mengasihi makhluk Allah, mereka akan dikasihi oleh Allah yang Maha Rahman. Oleh karena itu sayangilah siapa yang di bumi agar kamu disayangi oleh yang ada di langit. ${ }^{27}$

Menurut Ibn Tufail, segala wujud yang ada di alam ini, seperti tumbuhan dan hewan mempunyai tujuan tertentu. Buah misalnya, ia keluar dari bunga, kemudian menjadi masak dan ranum. Bijinya jatuh di tanah dan kemudian tumbuh lagi menjadi pohon. Apabila ada orang yang memetik buah itu sebelum mencapai pertumbuhannya yang lengkap maka perbuatannya patut dicela dan tidak bermoral, karena merintangi pertumbuhan buah tadi dalam mencapai tujuannya yang alami, sehingga bisa berakibat kelompok tumbuhan yang memiliki buah itu akan punah.

Ibn Tufail mengatakan bahwa orang tidak boleh memakan habis tumbuhan atau hewan yang langka karena hal itu berarti memusnahkan jenis mahluk hidup itu, untuk selama-lamanya. Akhlak yang terpuji di alam ini adalah usahanya yang terus menerus melestarikan alam sekitarnya. ${ }^{28}$

Ada banyak sekali ayat-ayat yang menyebutkan larangan atau menunjukkan keburukan orang yang melakukan kerusakan di muka bumi, baik kerusakan secara fisik maupun kerusakan secara sosial, yang pada akhirnya akan melahirkan kerusakan fisik juga. Setidaknya ada 44 ayat yang menyebut tentang hal itu. Di antata ayat-ayat tersebut adalah :

1) Dan bila dikatakan kepada mereka, 'Janganlah kamu membuat kerusakan di muka bumi.' Mereka menjawab, 'Sesungguhnya kami orang-orang yang mengadakan perbaikan.' ${ }^{29}$

${ }^{26}$ Hadits Riwayat Bukhari

${ }^{27}$ Hadits Riwayat Ahmad

${ }^{28}$ Djajadiningkrat, Surna T. Dan Budhisantoso S. (penyunting) (1997), Islam dam Lingleungan Hidup, Jakarta :Yayasan Swarna Bhumy

${ }^{20}$ QS al-Baqarah (2) : 11

${ }^{30} \mathrm{QS}$ al-Baqarah (2) : 205 
2) Dan apabila ia berpaling, ia berjalan di bumi untuk mengadakan kerusakan padanya, dan merusak tanam-tanaman dan binatang ternak, dan Allah tidak menyukai kebinasaan. ${ }^{30}$

3). Dan carilah pada apa yang telah dianugetahkan Allah kepadamu negeri akhirat, dan janganlah kamu melupakan bahagianmu dari duniawi dan berbuat baiklah sebagaimana Allah telah berbuat baik, kepadamu, dan janganlah kamu betbuat kerusakan di bumi. Sesungguhnya Allah tidak menyukai otang-orang yang berbuat kerusakan. ${ }^{31}$

4) Dan ketika Musa memohon air untuk kaumnya, lalu Kami berfirman, 'Pukullah batu itu dengan tongkatmu.' Lalu memancarlah daripadanya dua belas mata air. Sungguh tiap-tiap suku telah mengetahui tempat minumnya. Makan dan minumlah rezki Allah, dan janganlah kamu berkeliaran di muka bumi dengan berbuat kerusakan. ${ }^{32}$

5) Dan janganlah kamu membuat kerusakan di muka bumi, sesudah memperbaikinya dan berdo'alah kepada-Nya dengan rasa takut dan harapan . Sesungguhnya rahmat Allah amat dekat kepada orang-orang yang berbuat baik. ${ }^{33}$

6) Dan ingatlah olehmu di waktu Tuhan menjadikam kamu pengganti-pengganti sesudah kaum 'Aad dan memberikan tempat bagimu di bumi. Kamu dirikan istana-istana di tanah-tanahnya yang datar dan kamu pahat gunung-gunungnya untuk dijadikan rumah; maka ingatlah nikmat-nikmat Allah dan janganlah kamu merajalela di muka bumi membuat kerusakan. ${ }^{34}$

7) Dan janganlah kamu merugikan manusia pada hak-haknya dan janganlah kamu merajalela di muka bumi dengan membuat kerusakan; ${ }^{35}$

Untuk itu, tidak perlu diragukan lagi, Islam secara tekstual maupun kontekstual mendukung, menganjurkan bahkan memerintahkan umat manusia agar menjaga lingkungannya, melestarikan dan melarang merusaknya.

\section{Peran Dakwab Dalam Menyelamatkan Lingkungan}

Islam adalah agama dakwah. Kesempurnaan ajaran Islam mengharuskan umatnya untuk menyampaikan kebenaran tersebut kepada umat yang lain dan bersama-sama menuju surga. Oleh karena itu, sifat ajaran Islam adalah keselamatan. Keselamatan dapat dicapai dengan menganjurkan, menjaga, membangun dan melestarikan kebaikan. Namun itu saja tidak cukup. Manusia mempunyai sifat

\footnotetext{
${ }^{31}$ QS al-Qashash (28) : 77

${ }^{32}$ QS al-Baqarah (2) : 60

${ }^{33}$ QS al-A'raf (7) : 56

${ }^{34}$ QS al-A'raf $(7): 74$

${ }^{35}$ QS as-Syu'araa' (26) : 183
} 
kecenderungan untuk menyalahi kebenaran dan kebaikan. Untuk itu diperlukan suatu tindakan untuk mencegah keburukan. Dalam bahasa agama disebut dengan al amru bil ma'ruf wan nabyu 'anil mungkar. Artinya menganjurkan kebaikan dan mencegah kemungkaran.

Islam juga dikenal agama yang dekat dengan lingkungan. Aktivitas sehari-hari yang berkaitan dengan ibadah ritual sangat erat bersinggungan dengan lingkungan. Sebuah ilustrasi perbincangan ulama dan umara digambarkan oleh Fachruddin dalam tulisannya. Pada suatu hari, Emil Salim -yang waktu itu menjadi Menteri Kependudukan dan Lingkunang Hidup - datang menghadap ulama besat dan Ketua Majelis Ulama Indonesia (MUI) Prof. Haji Abdul Malik Karim Amarullah (HAMKA), dan betharap pada ulama agar dapat memberikan bantuan dalam menyadarkan ummat Islam terhadap lingkungan. Emil mengatakan, "Buya, apa yang bisa dilakukan ummat Islam dalam melestarikan lingkungan hidupnya," Prof Hamka, dengan arif menjawab: tidak ada yang salah dengan ajatan Islam dalam soal lingkungan hidup. "Tetapi kesalahan terjadi pada bagaimana cara kita mengajarkan Islam kepada masyarakat." Kata Buya Hamka, umat Islam akan tersentuh jika segala hal praktis dapat langsung dirasakan mereka. Misalnya umat Islam harus shalat lima waktu. Maka diperlukan air wudhu yang mensucikan. Dari mana umat mendapatkan air bersih? Dari sungai yang mengalir dari air tanah yang sah yang memenuhi persyaratan untuk menghadap khaliqnya. Dengan demikian setiap ummat Islam harus memelihara air serta sumbersumbernya agat mereka bisa beribadah kepada Allah. Jadi wajib hukumnya umat memelihara sumber-sumber air tersebut. ${ }^{36}$

\section{Prinsip Dakwah Islam}

Dalam prinsip dakwah Islam, mencegah keburukan lebih berat daripada mengajak kepada kebenaran. Sebab, mencegah keburukan mengandung resiko. Oleh karena itu penekanan terhadap mencegah kemungkaran sangat kentara sekali di dalam ajaran Islam. Salah satunya dengan sabda Nabi Muhammad saw yang seringkalidikutip dalam berbagai kesempatan. Beliau saw bersabda :

Barang siapa di antara kalian melihat kemungkaran, maka ubahlah dengan tangan (kekuasaan)-nya. A pabila tidak sanggup, maka ubahlah dengan lisannya. Jika tidak sanggup maka ubahlah dengan hatinya. Yang demikian itu adalah selemah-lemah iman. ${ }^{37}$

Ini mengandung arti seorang penguasa wajib menggunakan kekuatannya untuk mencegah kemungkaran. Saat ini kita melihat kemungkaran begitu nyata dalam kerusakan lingkungan. Tindakan penguasa, terutama aparat terkait sangat relevan

\footnotetext{
${ }^{36}$ Fachruddin Mangunjaya (2005), Agama Mengatasi Krisis Lingkungan, www.tropica.or.id

${ }^{37}$ Hadits Riwayat Muslim
} 
dengan hadits ini. Adanya pembuangan limbah industri, penebangan liar hutan, polusi udara, air dan tanah serta berbagai macam kerusakan lingkungan lainnya menjadi tanggung jawab mereka yang memiliki kekuasaan. Namun apa daya, oknum-oknum penguasa tidak saja mereka tidak mencegah kemungkatan, namun justru menjadi pelaku kerusakan itu sendiri. Sementara, penguasa yang bersih dan mencoba untuk mencegah kemungkaran itu sendiri sepertinya tidak berdaya karena ruwetnya sistem dan kekuasaan tak terlihat (invisible hand) dari oknum perusak lingkungan.

Sebagai agama dakwah, Islam mewajibkan umatnya baik secara individu maupun kolektif untuk melakukan dakwah. Allah dan Rasul-Nya telah menyampaikan perintah tersebut dan tidak ada alasan untuk menolaknya. Allah berfirman :

Kamu adalah umat yang terbaik yang dilahirkan untuk manusia, menyuruh kepada yang ma'tuf, dan mencegah dari yang munkar, dan beriman kepada Allah. sekiranya ahli Kitab beriman, tentulah itu lebih baik bagi mereka, di antara mereka ada yang beriman, dan kebanyakan mereka adalah orang-orang yang fasik. ${ }^{38}$

Dan hendaklah ada di antara kamu segolongan umat yang menyeru kepada kebajikan, menyuruh kepada yang ma'ruf dan mencegah dari yang munkar; merekalah orang-orang yang beruntung. ${ }^{39}$

Sedangkan Nabi Muhammad saw menyuruh umatnya untuk melakukan dakwah sekecil apapun, asal itu berupa kebenaran. Beliau saw bersabda :

- Sampaikan apa-apa dariku walaupun satu ayat. ${ }^{40}$ -

Jadi, apapun yang diketahui oleh seorang muslim berupa kebenaran harus disampaikan kepada orang lain dengan cara yang bijak. Dengan mengaitkan ayat kewajiban dakwah dan anjuran untuk mencegah kemungkaran sebenarnya sudah cukup bagi seorang mukmin sebagai dasar untuk memelihara lingkungan dan mencegah kerusakannya. Ditambah lagi adanya sebuah hadits yang sangat cocok sekali sebagai gambaran dan akibat orang yang tidak mau mencegah kerusakan. Dalam sebuah riwayat disebutkan bahwa Rasulullah saw. pernah bersabda :

Ada suatu rombongan naik sebuah kapal. Lalu mereka membagi-bagi tempat dan masing-masing mereka mendapat tempatnya sendiri-sendiri. Tiba-tiba salah

\author{
${ }^{38} \mathrm{QS}$ Ali Imran (3) 110 \\ ${ }^{30} \mathrm{QS}$ Ali Imtan (3) : 104 \\ ${ }^{+0} \mathrm{M}$-Natsir (1983), Fighud Dakwah, Jakarta : Media Dakwah, p.110
}


seorang dari mereka melubangi tempat yang didudukinya dengan sebuah kampak. Mereka bertanya, "Apa yang telah kau perbuat ?" Ia menjawab, "Ini tempatku sendiri dan aku boleh berbuat padanya semauku !" Jika mereka terus memegang tangannya (mencegahnya) maka otang itu akan akan selamat. Tetapi sekiranya mereka biarkan saja orang itu berbuat begitu, orang itu akan binasa dan semua orang dalam kapal akan binasa. ${ }^{41}$

Analogi penumpang kapal dengan masyarakat sering dipakai para da'i untuk menyampaikan pesan bahwa masyarakat harus peduli terhadap kerusakan moral yang dilakukan oleh sebagian orang. Seperti zina, kalau masyarakat tidak peduli maka seluruhnya bisa terkena akibat perbuatan zina dari segelintir orang tersebut. Masalah-masalah sosial dan moral keagamaan sering disinggung dengan menggunakan perumpamaan ini. Namun jarang disinggung masalah kerusakan fisik dan lingkungan hidup. Padahal perumpamaan ini sangat cocok menggambarkan tentang ulah sebagian orang yang merusak lingkungan. Jika ada seseorang atau sebagian orang membuang sampah di selokan maka apabila yang lain tidak peduli akan terjadi banjir yang menimpa keseluruhan warga. Juga seseorang atau sekelompok orang menebang hutan lindung maka masyarakat yang lain akan terkena dampak banjir atau hilangnya kesuburan di tanah-tanah mereka. Seseorang yang memanaskan motornya dengan menggeber mesin akan membuat polusi suara dan udara yang dirasakan bagi masyarakat di sekitar rumahnya.

Demikian pula apabila ada sekelompok orang yang melakukan perbuatan yang bisa merusak ozon dan membuat efek rumah kaca akan membuat bumi makin panas dan timbulnya berbagai penyakit kronis seperti kanker. Tindakan seperti ini persis yang disebutkan di dalam hadits di atas bagaikan orang yang melubangi badan kapal. Apabila yang lain tidak peduli maka yang akan tenggelam tidak saja orang yang melubangi kapal, tapi juga meluruh penghuni kapal. Peringatan Nabi Muhammad saw ini sangat cocok menjelaskan kepedulian umat terhadap kerusakan lingkungan. 2. Cara dan Materi Dakwah

Hanya saja diperlukan cara yang bijak dalam menyampaikan kebenaran, baik berupa amar ma'nuf maupun nabi mungkar. Disebutkan di dalam Al Quran bahwa cara menyampaikan dakwah yang baik ada tiga. Pertama adalah dengan hikmah (bilhikmab), kedua dengan peringatan yang baik (walmau'idhatil hasanah), ketiga dengan atgumen yang kuat (wa jaadilhum billati biya absan). ${ }^{42}$

Petunjuk Allah dalam berdakwah ini sangat relevan apabila jika diterapkan kepada dakwah memperbaiki lingkungan hidup. Dakwah dengan penuh kebijaksanaan arah mengarahkan seseorang kepada segi manfaat di balik ajakan kebenaran tersebut.

\footnotetext{
${ }^{41}$ Hadits Riwayat Bukhari

${ }^{42} \mathrm{QS}$ an-Nahl (16) : 125
} 
Mungkin dalam jangka pendek kurang menguntungkan atau tidak membawa manfaat. Tapi dalam kurun waktu yang relatif lama akan menyelamatkan semua pihak. Seorang da'i juga harus memberikan pemahaman yang baik kepada mad'u (orang yang didakwahi). Mereka harus, diberikan argumen-argumen yang kuat sehingga timbulnya keinginan kuat untuk memperbaiki lingkungan sekitar datangnya dari dalam jiwa mereka sendiri. Bukan sebuah keterpaksaan.

Mengingat masalah yang dibahas tidak seperti biasanya, dakwah mengenai pencegahan kerusakan lingkungan harus disampaikan dengan cara yang baik dan benar seperti ayat di atas. Bahasa dan media harus diberikan sesuai dengan kondisi mad'u. Tidak kalah penting adalah momen penyampaian yang tepat (moment of trutb). Bisa jadi dari segi bahasa dan media sudah tepat tapi waktu dan tempatnya kurang tepat sehingga dapat lingkungan tidak bisa masuk. Dengan memberikan pengertian yang baik, tutur bahasa yang santun dan lembut, ditambah argumen yang kuat dan meyakinkan dakwah lingkungan akan berjalan dengan efektif. Sebuah peribahasa mengatakan, "Kata-kata yang bijak sering tidak didengar, tetapi kata-kata yang lembut akan selalu diingat."

Cara dakwah yang demikian akan mudah membawa seseorang kepada kebaikan dan meninggalkan kerusakan. Masyarakat menjadi lebih cepat reaksinya untuk diajak menjaga lingkungan hidupnya serta segera menghentikannya apabila mereka melakukan kerusakan. Kadang kala amar ma'nuf nabi mungkar tidak berjalan dengan lancar hanya karena cara melakukannya tidak sesuai dengan ajaran Allah.

Sedangkan mengenai materi, hatus kita akui, sedikit sekali para da'i dan mubaligh yang menyinggung masalah kerusakan lingkungan. Dakwah Islam masih banyak berkutat ke masalah penguatan aqidah, fiqh, akhlak terhadap sesama manusia, pergerakan, politik, ekonomi dan sebagainya. Mereka merasa bahwa urusan lingkungan hidup merupakan urusan orang lain. Urusan pemerintah dan lembagalembaga swadaya masyarakat (LSM). Sering kali ayat-ayat tentang alam dibacakan, terutama apabila terjadi bencana alam banjir, gempa, maupun kerusakan yang lain. Namun seringkali hal tersebut dikaitkan dengan kerusakan moral yang bisa jadi merupakan sebab kerusakan tersebut.

Memang ada skala prioritas, antara memperbaiki moral, sosial dan lingkungan. Barangkali perbaikan moral dan sosial dirasakan lebih. dahulu dibenahi. Namun, melihat fakta yang terjadi, sudah waktunya dakwah kepada lingkunganpun harus diberikan porsi yang cukup besar.

3. Saluran dan Media Dakwah

Faktor penting dalam dakwah lingkungan adalah sarana penyampaian dakwah tersebut. Masing-masing sarana dan media mempunyai kelebihan dan kekurangan, tergantung pada kebutuhan masing-masing dan kesempatan yang bisa dipergunakan. Semakin berkembang teknologi, sarana dakwah pun bertambah. Pengelolaan atas 
waktu dan tempat juga membuat dakwah semakin hari makin berkembang. Ada beberapa sarana dan media dalam berdakwah, khususnya dalam dakwah untuk pemeliharaan lingkungan. Bagi seorang da'i, kemampuan untuk memanfaatkan setiap situasi dansarana dakwah sangat penting. Nabi Muhammad saw dalam berbagai kesempatan selalu berusaha untuk menyampaikan kebenaran. Dan setelah selesai menyampaikan dakwah, beliau selalu bersabda, "Bukankah aku sudah menyampaikan?"

Kesempatan yang berusahasarana dan media dakwah mempengaruhi efektivitas penyampaian dakwah lingkungan. Semakin sering seorang da'i menyampaikan dakwah mengenai pengelolaan lingkungan dalam berbagai kesempatan dan media tersebut maka semakin cepat masyarakat sadar akan pentingnya kelestarian lingkungan.

a) Ceramah dengan Interaksi Langsung

Bagi seorang da'i, pertemuan atau interaksi langsung banyak sekali didapatkan. Sebab, tugas da'i adalah menyampaikan dakwah. Institusi-institusi kelembagaan dan peribadatan Islam telah menyediakan sarana itu. Kesempatan interaksi langsung ini bisa dilakukan di antaranya dalam kesempatan kbutbab Jumat. Para khatib seyogyanya dapat menyampaikan dalam berbagai kesempatan khutbah untuk menyinggung masalah pelestarian lingkungan. Kita dapat bayangkan bahwa hampirhampir di setiap dusun, desa, RW bahkan RT terdapat masjid yang dipergunakan untuk shalat Jumat. Apabila kesadaran para khatib untuk menyampaikan masalah lingkungan ini tinggi maka akan makin mudahlah pemahaman tentang lingkungan ini berkembang di masyarakat. Lebih-lebih sifat dari khutbah Jumat adalah searah, artinya tidak bakal ada complain dari jamaah apalagi jika isi yang disampaikannya cukup menarik. Senada dengan khutbah Jumat adalah khutbah Idul Fitri dan Idul Adha. Kesempatan khutbah mengenai lingkungan di kesempatan ini akan sangat efektif.

Selain khutbah Jumat, peran dakwah di kalangan Majlis Taklim tidak bisa diremehkan. Majlis Taklim adalah kelompok pengajian yang terdapat di beberapa daerah seperti satu kampung atau satu kompleks perumahan. Biasanya terdiri dari ibu-ibu rumah tangga yang mengisi waktu dengan pengajian. Majlis Taklim merupakan satuan terkecil dalam kajian keislaman meskipun belum tentu semua daerah ada. Namun keberadaan lembaga tersebut sangat efektif untuk menyampaikan sesuatu karena pertemuannya sangat intens. Mereka bertemu bisa seminggu sekali atau dua kali, ada keterikatan dan keanggotaan, ada pula yang bebas. Di antara Majlis Taklim pun kadang kala membentuk perkumpulan atau ikatan. Apabila media ini dapat dimanfaatkan dengan baik untuk menyampaikan perihal lingkungan hidup maka sedikit banyak akan membantu percepatan kesadaran masyarakat soal lingkungan. 
Beda dengan khutbah Jumat, penyampaian dakwah lingkungan di komunitas Majlis Taklim bisa dibantu dengan teknologi. Misalnya dengan menggunakan film atau infocus. Penyampaian dengan cara demikian akan lebih menarik dan mengena karena diberikan dalam bentuk alat bantu audio visual. Dengan demikian, semua aspek potensi untuk menerima dakwah lingkungan bisa dipergunakan dengan baik. Hasilnya pun tentu lebih baik dibandingkan hanya ceramah biasa.

Kelompok yang lebih intens dalam kajian Islam adalah kelompok yang lebih kecil dari Majlis Taklim, yaitu kelompok pengajian yang biasa disebut dengan balaqab, liqa' atau usrab. Keterikatan antar anggota lebih ketat karena untuk mengikuti pengajian tersebut sudah melalui seleksi yang cukup ketat. Mereka yang mengikuti halaqah sudah mempunyai persepsi yang sama tentang Islam dan kehidupan. Apabila dakwah mengenai lingkungan dapat masuk ke dalam komunitas ini, efektivitas penyampaiannya akan sangat tinggi.

Mereka biasanya mengaji tanpa bantuan teknologi. Tapi kajian yang dilakukan lebih mendalam dan intensif. Kesadaran mereka tinggi untuk mendapatkan ilmu baru atau mengamalkan sesuatu karena sudah dipicu oleh kesamaan visi dan misi. Kepercayaan mereka atas pembimbingnya (murabbi atau musyrif) sangat tinggi sehingga mudah memasukkan ide-ide tentang hakikat lingkungan hidup kepada anggota komunitas tersebut.

Hanya saja, melihat fakta di lapangan, kelompok pengajian halaqah ini sepertinya masih belum tersentuh untuk membicarakan masalah lingkungan. Upaya dan usaha memberikan kesadaran akan Islam dan penerapannya di lapangan saat ini menjadi prioritas bagi mereka. Di sinilah sebenarnya tantangan dari aktivis lingkungan agar bisa menyelipkan dakwah mengenai lingkunga di kalangan Islam komunitas ini. Meskipun tidak banyak, tapi mereka adalah kader yang handal sehingga diharapkan ketika bergerak di masyarakat mereka akan mudah memberikan pengaruh kepada masyarakat umum, terutama soal lingkungan.

Sementara itu, untuk dakwah yang sifatnya umum (tabligh akbar) dapat kita jumpai pada peringatan hari-hari besar agama Islam (PHBI) seperti tahun baru Islam 1 Muharam, Maulid Nabi Muhammad, Isra' Mi'raj, Nuzulul Quran dan sebagainya. Biasanya yang hadir dalam acara seperti ini cukup banyak dan jamaah mau dan sengaja ingin mendengarkan sesuatu dari penceramah. Dakwah mengenai lingkungan di forum seperti ini tentunya sangat efektif.

Para da'i yang ceramah biasanya adalah kyai kondang dan sudah terbiasa berceramah. Dengan memasukkan materi tentang lingkungan hidup maka banyaknya massa pendengar ceramahnya akan mudah diberikan pemahaman soal lingkungan. Namun sayangnya, saat ini jarang kita dengan ada tabligh akbar yang menyinggung masalah kerusakan lingkungan hidup yang makin hari makin parah. Diharapkan kesadaran lebih tinggi dari para da'i yang melakukan tabligh akbar untuk dapat 
memberikan materi masalah lingkungan di dalam ceramahnya.

Media lain adalah mereka yang akan berangkat menunaikan ibadab baji. Apabila dilihat jumlah jamaah haji asal Indonesia, tentu jumlahnya tidak main-main. Sekitar 200 ribu lebih setiap tahun jamaah haji asal Indonesia berangkat ke tanah suci. Sebelum berangkat, biasanya mereka mendapatkan pelajaran mengenai manasik haji yang berlangsung intensif selama beberapa kali pertemuan. Momen ini sangat baik untuk menjelaskan masalah lingkungan karena mereka akan menjadi tamu Allah di tanah suci, di mana salah satu ketentuan berada di sana tidak boleh memetik atau merusak pohon seenaknya. Di tanah suci lingkungan harus dijaga, terutama masalah kebersihan. Apabila momen ini dapat dimanfaatkan, ada banyak hal bisa didapatkan. Salah satunya adalah pemahaman jamaah haji tentang menjaga lingkungan hidup tempat tinggalnya agar tidak rusak dan tercemar. Haji dan hajah yang jumlahnya jutaan itu akan mudah menyebatkan pemahaman ini kepada masyarakat di sekitarnya.

Forum yang lain yang mungkin bisa dimanfaatkan adalah forum Walimatul Ursy atau pesta pernikahan. Pada waktu-waktu tertentu akan kita dapati bahwa hampir setiap minggu ada penyelenggaraan walimah pernikahan di berbagai tempat. Ada khutbah nikah di dalam acara tersebut di mana dapat dimanfaatkan untuk menasihati kedua mempelai dan para hadirin yang berada di tempat tersebut. Penceramah atau pemberi nasihat bisa saja menyelipkan dakwah tentang lingkungan di forum tersebut tanpa adanya interupsi. Dan masih banyak lagi momen dan kesempatan yang dapat dimanfaatkan untuk menyebarkan pemahaman tentang pentingnya melindungi dan melestarikan lingkungan hidup.

b) Media Cetak

Selain berinteraksi langsung dengan massa, cara atau media lain yang dapat dipakai untuk berdakwah, dan juga dakwah lingkungan, adalah dengan media cetak. Apabila kita amati, hampir-hampir setiap masjid pada hari Jumat mengedarkan buletin dakwah. Setiap jamaah yang hadir dipersilakan mengambil buletin tersebut. Meskipun sederhana, penyebaran buletin tersebut sangat efektif dalam memasukkan sebuah pemikiran ke dalam benak pembacanya. Apalagi bagi jamaah yang datang awal, ia akan mengisi waktu dengan membaca buletin tersebut dengan penuh penghayatan.

Untuk itu dakwah lingkungan melalui media buletin Jumat sangat efektif. Tidak buletin Jumat saja, ada beberapa anggota kelompok masyatakat yang secara reguler mengeluarkan buletin dakwah. Apabila aktivitas lingkungan hidup ingin lebih mudah menyebarkan pemikitannya maka sarana buletin dakwah ini harus dicoba. Sebab, kenyataan di lapangan saat ini tidak banyak buletin yang membahas tentang masalah kerusakan lingkungan.

Buletin dakwah hanyalah salah satu media cetak yang dapat dimanfaatkan. 
Media cetak yang lain banyak, seperti majalah, koran, tabloid dan buku. Di jaman sekarang ini, terutama bagi masyarakat perkotaan, koran sudah menjadi santapan wajib di pagi atau sore hari. Hampir setiap keluarga di perkotaan berlangganan atau membaca koran. Apabila koran adalah media yang banyak dibaca orang, mengapa kita masih ragu untuk memanfaatkan media tersebut dalam penyuluhan masalah lingkungan. Dakwah lingkungan yang bijak, diikuti dalil-dalil dari Al Quran dan hadits akan menambah keyakinan masyarakat dalam menunaikan ajaran agamanya memelihara lingkungan.

Buku juga menjadi sarana yang efektif. Memang penyebarannya tidak seluas koran atau majalah. Namun buku tak lekang dimakan jaman. Buku bisa disimpan dalam kurun waktu yang telatif lama dibanding koran yang barangkali sehari dua hari sudah dibuang. Kemudian, orang yang membaca buku dapat lebih leluasa dan mendalam dalam memahami apa yang disampaikan dalam buku tersebut. Oleh karena itu sangat penting dakwah lingkungan di sektor perbukuan. Sayangnya, saat ini buku tentang lingkungan hidup dipandang dari sudut ajaran agama (Islam) masih sangat minim.

Sarana lain yang dapat dimanfaatkan dari media sangat banyak. Tidak perlu terpaku dengan sesuatu yang sudah ada. Kita dapat secara kreatif menggunakan media ini untuk menyebarkan informasi-informasi tentang bagaimana tusaknya alam ini. Bagi yang mempunyai dana lebih, brosur-brosur yang menggugah hati agar ikut menyelamatkan lingkungan harus diperbanyak. Pembagian ini menjadi sangat efektif karena biasanya penerimanya gratis. A pabila ada waktu luang, brosur-brosur itu akan dibacanya. Hanya saja bila tampilannya kurang bagus dan saat memberikannya kurang tepat, bisa jadi brosur tersebut malah dibuang ke tempat sampah.

c) Media Elektronik

Apabila media cetak dinilai efektif dalam penyebaran sebuah ide, media elektronik menduduki peran yang lebih penting. Sebab media elektronik telah memanfaatkan hampir semua unsur indra untuk menyampaikan sebuah informasi. Kekuatan audio visual akan lebih mengefektifkan penggunaan sarana ini dalam menyebarkan dakwah lingkungan.

Untuk itu, banyak penceramah agama masuk dunia televisi untuk berceramah di sana. Beberapa ustadz malah diberikan jam khusus yang mengisi secara rutin. Ustadz yang ceramahnya enak biasanya sudah ditunggu-tunggu sebelum acara dimulai. Jamaah pemirsa akan memperhatikan apa yang akan disampaikan ustadz favoritnya dalam pengajian di televisi tersebut. Kesempatan yang baik ini merupakan momen yang tepat untuk melakukan dakwah perbaikan lingkungan. Untuk itu sangat penting pembekalan terhadap para ustadz yang ceramah di televisi.

Kehidupan dunia modern saat ini didominasi oleh peran media elektronik. Hampir-hampir tidak ada keluarga yang tidak mempunyai televisi dan radion sampai 
ke pelosok-pelosok. Bahkan saat ini mempunyai komputer pribadi $(\mathrm{P} C=$ Personal Computer) di setiap rumah-rumah di perkotaan sepertinya sudah menjadi ketwajaran. Televisi hampir-hampir mengunjungi setiap rumah tanpa pandang bulu rumah siapa yang dikunjunginya. Dakwah lingkungan melalui televisi harus dijadikan sebuah tradisi.

Selain ceramah keagamaan yang menyelipkan soal-soal lingkungan hidup, pemanfaatan media elektronik masih sangat luas. Acara yang berada pada waktu prima (prime time) yang banyak digemari pemirsa adalah sinetron. Dunia dakwah sudah mulai merambah acara satu ini meskipun akhirnya betalih haluan. Bukan lagi sinetron teligi, tapi sinetron mistik. Ada baiknya, dakwah mengenai lingkungan dapat dikemas secara menarik dalam sebuah sinetron. Pemirsa tidak akan merasa digurui dan secara pribadi akan mendukung program pelestarian lingkungan. Sinetron yang dipandang sebagai hiburan tersebut menyimpan nuansa dakwah terutama berkenaan dengan masalah lingkungan.

Satu lagi peran media elektronik yang sangat efektif adalah website atau situs. Sekarang ini banyak sekali lembaga maupun pribadi yang menyampaikan gagasannya, ide-ide dan dakwahnya melalui internet. Situs atau website dibangun dan diberikan muatan dakwah. Tidak ada salahnya, pendidikan lingkungan diberikan di dalam dunia maya yang kian hari peminatnya kian bertambah. Dengan adanya website, masyarakat, terutama yang tidak suka berinteraksi langsung dengan para ustadz atau ahli akan mudah mengakses informasi tersebut. Dari balik komputer tersebut ia bisa menjelajah kemana-mana. Dengan menangkapnya maka pemahaman tentang pengelolaan lingkungan yang baik akan tertanam di benaknya.

d) Pembuatan aturan di Lingkungan Terbatas

Dari sekian banyak metode dakwah, penerapan apa yang didakwahkan melalui peraturan dan law enforcement merupakan yang paling efektif. Berkaitan dengan peran dakwah dalam pelestarian lingkungan hidup maka peran lembaga Islam seperti pesantren, perguruan tinggi Islam ataupun yayasan-yayasan Islam sangat dominan. Pata kyai atau pimpinan lembaga tersebut akan dengan mudah menerapkan suatu aturan yang mendukung terhadap pelestarian alam. Seorang kyai misalnya akan mewajibkan santri-santri dalam pesantrennya untuk hidup bersih dan tidak membuat polusi lingkungan. Ia juga bisa memerintahkan santri-santrinya untuk menanam dan memelihara pohon di sekitar lingkungan pesantren. Dengan demikian maka dakwah lingkungan dengan cara ini sudah langsung mengena. Reboisasi tidak lagi menjadi slogan tapi sudah dilaksanakan dan diamalkan. Ilmunya, baik ilmu agama maupun ilmu lingkungan sudah dipelajatinya di dalam kelas. Pengamalannya dilakukan di luar kelas melalui kegiatan-kegiatan yang memelihara kelestarian alam.

Yang terpenting dalam hal pemeliharaan kelestarian alam berkaitan dengan law enforcement adalah pemerintah itu sendiri. Jika pemerintah tegas maka siapa saja 
yang berusaha menghancurkan kapal kehidupan ini akan ditindaknya tanpa pandang bulu. Pemerintah akan selamat dan rakyat terhindar dari bencana.

Apabila manusia sudah berhasil mencegah kerusakan dan kemudian memelihara kelestarian lingkungan hidupnya, alam timbal balik pun akan diberikan alam kepada manusia. Allah melalui kekekuasan-Nya akan memerintahkan akan untuk memberikan manfaat sebanyak-banyaknya bagi kesejahteraan hidup manusia. Tidak sekedar tanaman, tapi juga hewan, air, tanah, api dan udara. Mereka, sebagaimana fungsinya diciptakan akan menjadi penyejuk dan sumber kenikmatan bagi manusia. Seperti terhadap manusia, apabila kita baik terhadap seseorang maka orang tersebut pun akan baik kepada kita. Jika manusia baik terhadap alam semesta maka Allah akan memerintahkan alam semesta untuk memberikan kebaikan seluasluasnya kepada manusia.

Sebagai contoh, ait. Penelitian terakhir telah menunjukkan bahwa air akan memberikan reaksi dengan membentuk kristal tergantung apa yang diberikan manusia kepadanya. Profesor Masaru Emoto dari Jepang telah membuktikan bahwa jika kita memperlihatkan kata "bahagia" kepada air maka air itu akan membentuk kristal dengan ukuran seimbang yang sangat indah seperti potongan permata. Sebaliknya, iar yang diperlihatkan kata "tidak bahagia" akan menghasilkan pecahan kristal dengan ukuran tidak seimbang. Kelihatannya air yang diperlihatkan kata "tidak bahagia" tersebut telah berusaha keras untuk membentuk kristal namun ia kehabisan tenaga karena kebahagiaan menghilang dari air tersebut. ${ }^{43}$

Itu hanyalah sebagian kecil yang diperlihatkan alam apabila manusia memelihara mereka dan menjauhkan kerusakan dari diri mereka. Dengan dakwah Islam yang selama ini berkembang, dakwah lingkungan bisa lebih efektif apabila dimasukkan di dalam salah satu program dakwah tersebut.

\section{E. Penutup}

Islam adalah agama yang sangat peduli terhadap lingkungan hidup. Banyak ayat Al Quran dan hadits Nabi yang menyatakan hal itu. Islam sangat menganjurkan untuk memelihara alam semesta dan melarang siapa saja untuk berbuat kerusakan, terutama terhadap alam. Namun kenyataan di lapangan cukup ironis. Sedikit sekali dari para da'i yang ceramahnya menyinggung masalah lingkungan hidup.

Para ulama seharusnya banyak menggali dan menafsirkan ayat-ayat Allah mengenai lingkungan sekaligus menguasai fakta mengenai kondisi lingkungan hidup saat ini. Penguasaan mereka terhadap lingkungan hidup akan membuat para da' $i$ memasukkan isu lingkungan dalam setiap dakwahnya. Sarana dan media dakwah

${ }^{43}$ Masaru Emoto (2006), The True Power of Water, terjemahan Azam transalator, Hikmah Air Dalam Olabjizwa, Bandung: MQ Publishing 
yang ada akan dimanfaatkan seoptimal mungkin agar umat maupun masyarakat luas segeta sadar dan peduli untuk memikirkan lingkungan hidupnya.

Potensi yang sangat besar dalam sarana dan media dakwah sudah seharusnya menjadi perhatian bagi pemerintah, aktivis lingkungan dan para ulama sendiri dan upaya menahan kerusakan alam saat ini.

\section{DAFTAR PUSTAKA}

Djajadiningkrat, Surna T. Dan Budhisantoso S. (penyunting) (1997), Islam dan Lingkungan Hidup, Jakarta :Yayasan Swarna Bhumy

Fachruddin Mangunjaya (2005), Agama Mengatasi Krisis Lingkungan, artikel dalam situs www.tropika.or.id

Anjang AS, Hatian Pikiran Rakyat edisi 7 Juni 2004

Jalaluddin As Suyuthi (tidak bertahun), al-Jami'us Shagir, Maktabah Darul Ihya'ilkutubil Aarabiyyah, Indonesia

Larry Gonick dan Alice Outwater (2004), The Cartoon Guide to The Environment terjemahan Ismunandat dan Tim KPG, Kartun Lingkungan, Jakarta : Kepustakaan Populer Gramedia

M. Natsir (1983), Fiqhud Dakwah, Jakatta : Media Dakwah

Mary Evelyn Tucker dan John Grim, Kebangkitan Aliansi Agama dan Ekologi, www.tropika.or.id

Masaru Emoto (2006), The True Power of Water, terjemahan Azam Transalator, Hikmah Air Dalam Olabjiwa, Bandung : MQ Publishing

Nabiel Fuad Al-Musawa (2005), Islam dan Lingkungan Hidup, artikel dalam situs www.kotasantri.com

Walhi (2005), Pernyataan 25 tahun Wahana Lingkungan Hidup Indonesia: Saatnya Kita Berubah, artikel dalam situs www.walhi.org

WWF Indonesia (2006), Perlindungan Lingkungan Hidup Bagian Penting dari Ajaran Islam, Press Release WWF-Indonesia tanggal 8 Februari 2006 dalam situs www.wwf. or.id 